\title{
A QUALITATIVE STUDY ON STUDENTS BEHAVIOR TOWARD SUDDEN ONLINE LEARNING POLICY
}

\author{
Darman Fauzan Dhahir \\ Balai Besar Pengembangan SDM dan Penelitian Komunikasi dan Informatika Makassar, Indonesia \\ darm007@kominfo.go.id
}

\begin{abstract}
Education stakeholders in Indonesia have made rapid adjustments due to the Coronavirus disease 2019 (COVID19) pandemic outbreak that demanded social distancing to avoid it. Yayasan Pendidikan Budi Utomo Makassar also issued a policy that changed the learning methods from offline to online. The current research was aimed to find out the behaviors of students facing this sudden policy. It was conducted with a qualitative approach. Data were collected from observations of several Yayasan Pendidikan Budi Utomo Makassar's students. The results showed that students obeyed the policy. Some of them learned and did the tasks as expected, but some others skipped the lessons, postponed doing assignments, and complained through the online communication media that had been provided.
\end{abstract}

Keywords: Adaptation; online learning; students' behavior; students' communication style; sudden change.

\section{INTRODUCTION}

The COVID-19 pandemic has brought impacts to the education system in Indonesia. Many analyses stated that it spreads rapidly through human contacts, so then stakeholders, including the Indonesian government, are establishing physical distance, social distance, and self-quarantine policy. As a result, the conventional learning methods that emphasize physical face-to-face interactions between teachers and students suddenly turn to distance computer or mobile device mediated learning [1] which is well known as e-learning [2, p. 8].

The policy has been also adopted by Yayasan Pendidikan Budi Utomo Makassar which runs junior and senior high school education integrated with Islamic boarding schools. Since the beginning of April 2020, the teaching and learning process has been conducted online. It utilizes Kelase, an online learning platform that is claimed as a flexible and easy use application. It is intended as an educational institution social network. It is available in the form of an android application, and can also be accessed using internet browsers so that it can be accessed anytime and anywhere [3].

This sudden shift policy decision may become a challenge for the students. That is why the current research is conducted to find out how these students adapt to the rapid change of their learning methods.

According to Hase, learning can occur if students are ready for learning rather than the teachers [4]. Regarding the readiness, previous studies which used eight factors, such as psychological readiness, sociological readiness, environmental readiness, human resource readiness, financial readiness, technological skill (aptitude) readiness, equipment readiness, and content readiness, found that in Yogyakarta, Indonesia, junior and high schools are commonly at a 'quite ready level' in e-learning system implementation [5], [6].

Besides of readiness, e-learning also requires students' maturity and discipline [7]. The lack of adolescent discipline can lead them astray. Especially if they do not get proper direction from their parents. Without parents' control, some young students are reportedly tempted to access entertainment and social media content that is not related to the lesson, even though when they first opened the internet they intended to learn [8]. The problem is that most parents in Indonesia are ignoring their children's internet access [9], while students who failed in their courses tended to interact less frequently [10].

By using the Technology Acceptance Model (TAM) measurements, Sukainah, et al. reported that students of a university in Makassar who utilized Kelase, accept it at a very high level of acceptance [3]. In another hand, Zhang, et al. who questioned whether e-learning can replace classroom learning, found that e-learning has several disadvantages, such as lack of immediate feedback in asynchronous e-learning, increased preparation time for the instructor, not comfortable to some people, and potentially more frustration, anxiety, and confusion [7].

The sudden policy may also face the internet usage issue since it is not evenly distributed in Indonesia. In 2019, it was reported that internet penetration reached only $64 \%$ of Indonesia's 264 million population. Even then, 55.7\% was contributed by Java, while other regions contributed $21.6 \%$ (Sumatra), 10,9\% (Sulawesi, Maluku, \& Papua), 6,6\% (Kalimantan), and 5,2\% (Bali \& Nusa Tenggara) [11]. The noninternet users will probably find certain problems in its implementation.

Those Alpha generations, the latest millennial generation, are believed to be capable of quickly adapting information technology [12]. Unfortunately, it is not always a good attitude towards computers, directly proportional to students' attitudes towards e-learning [13].

A previous study that discussed student behavior in elearning mentioned that sometimes there are students who skip the lesson texts or videos because they do not want to linger in reading or listening to lectures that might be boring for them. they might prefer to directly ask questions about what they don't know rather than being busy looking for answers in the long text or video [7].

Responding to the first online learning experience, Chinese and American higher education students expressed feelings of 
isolation and frustration at the lack of nonverbal cues, and were challenged by dealing with verbally assertive group members. But on the contrary, they also claimed to like a self-sufficient format, the ability to attend classes without the hassles of parking or traveling, and the opportunity to reflect and compose a good verbal response [14].

\section{METHODS}

The current research uses a descriptive qualitative approach. It uses Grounded Theory, which is the discovery of theory. It is derived inductively from the study of the phenomena it represents. The theory is discovered, developed, and verified through systematic data collection and data analysis relating to the phenomenon [15].

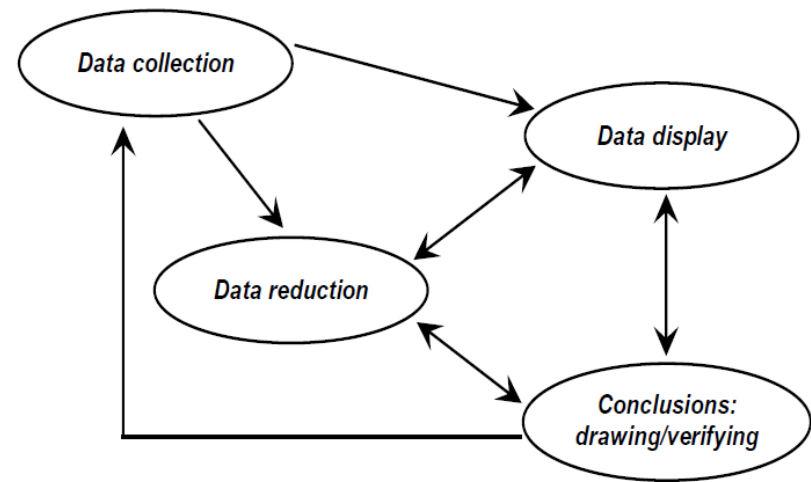

Fig. 1 Miles \& Huberman Interactive Model components of data analysis

Originally, the steps of the theory research consist of initiating research, data selection, initiation, and ongoing data collection, data analysis, and concluding the research [16], but because the interactive model seems to be similar, then it uses Miles \& Huberman Interactive Model of Analysis, which consist of Data Collection, Data Reduction, Data Display, and Conclusions as shown in Figure 1. Activities in the data analysis are carried out interactively and continuously until completion. It is intended so that there are no unexplained and unrecorded situations or contexts. The problem is, if that happens, researchers could forget the circumcision of the situation so that various related things can turn into meaningless fragments. Therefore, the data collection works result must be immediately followed by writing, editing, classifying, reducing, and presenting [17], [18].

The data collection had been done in April and May 2020. Students' behaviors toward the sudden shift of learning methods from conventional to online were observed. Data were retrieved by direct observation of the researcher on five students of Yayasan Pendidikan Budi Utomo Makassar (2 juniors: O1 and O2, and 3 seniors: $\mathrm{O} 3, \mathrm{O} 4$, and O5) who were implementing the 'learning from home' policy, and on online communication groups (WhatsApp, and Telegram messengers) which were involving all the students, the teachers, and the parents. The junior and the senior high school students were chosen as research subjects because generally they are familiar with the internet. They are the Generation $\mathrm{Z}$ (the senior students) and
The Generation Alpha (the junior students) who are natives in digital era [19]. The number of the direct-observant were only a little due to the limitation caused by the pandemic. The amount of that was directly observed was only a small amount due to limited space in the pandemic. However, something similar has been done by Ku \& Lohr [14] who analyzed the first experience of online learning by the Chinese students. At that time, there were only five Chinese students were taken. Moreover, in qualitative research the emphasis is not on the number of informants, but on the essence [20]. The online communication groups observation was needed for completing data of the direct observation. The interface of the Kelase was also observed. The observation technique is an alternative method of collecting social research data. It is one of the empirical scientific activities which relies on the senses. It bases on facts, without any manipulation. It is intended to produce a description, which can then give birth to a theory or hypothesis in qualitative research [21].

\section{RESULT AND DISCUSSION}

\section{A. General Description}

Yayasan Pendidikan Budi Utomo Makassar runs junior and senior high school education and integrates it with Islamic boarding schools. ICT is a subject that has been taught to students since they are in the first grade of junior high school. However, students who partly live far away from their parents are restricted to the use of communication devices. They are not permitted to bring mobile phones to school, or boarding, except at certain times, such as when examinations are based online. Long-distance communication between parents and children is delivered using official devices with the help of operators. Also, for reporting and updating students' needs and circumstances, parents and homeroom teachers form online communication groups.

Since the outbreak of the COVID-19 pandemic, when then the Indonesian government encouraged people to work, study, and worship at home, students were repatriated, and learning was changed from conventional methods to online. The platform used is Kelase.

\section{B. E-Learning Registration}

Notification of the implementation of the online learning policy was announced one week before the implementation day (April $1^{\text {st }}$, 2020) through the parents and the teachers' communication messenger groups (WhatsApp). It was accompanied by the application's manual guide and followed by the making of a new messenger group (Telegram) that involved all the students too. The new group is intended as a medium for announcements from the school, and as a media for consultation if students or parents find things that are unknown or confusing about school policies, or use the Kelase application.

Base on observation on a WhatsApp group ( $8^{\text {th }}$ Grade), on March $29^{\text {th }}$, some parents had reported that their children had been registered to the online application, but some other found 
had not been. Seen in Figure 2, the homeroom teacher announced the names of students who had not been yet registered that day.

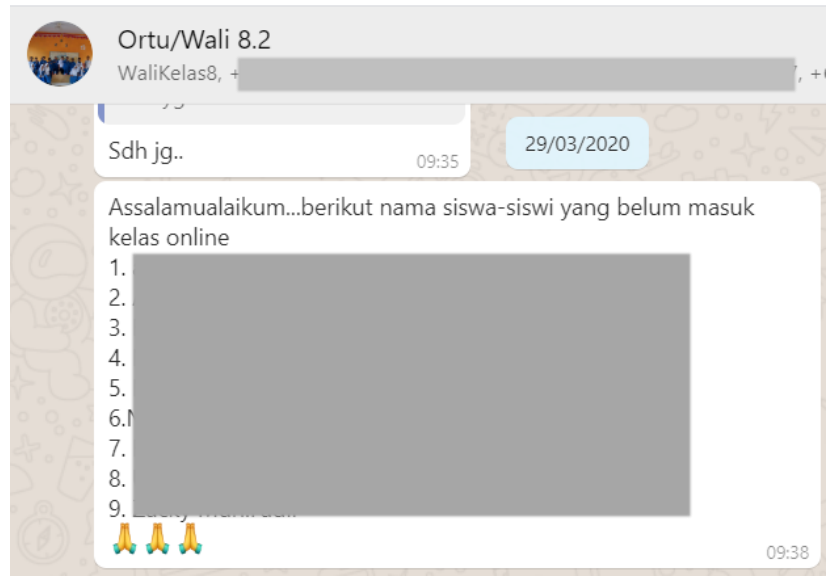

Fig. 2 Announcement about unregistered students

Some students were registered by their parents, but some of them registered themselves. Some registrants (both parents and students) followed the guidelines provided until they succeeded to register, but some failed. Some of those who failed, asked questions through the communication groups, while some other, especially the students, asked their classmates who they think were more understanding, as found in WhatsApp group when the teacher asked whether a student has been registered or not: "Assalamualaikum... Maaf mau tanya apa $A^{* * *} s d h$ terdaftar belum ya...?" the parent then answered that the student was being instructed by his classmate: " $A * * *$ lgi proses mau daftar bu'...lgi di ajar jg sma tmn $2 x$ di grup kelas." After that day, the teacher has never been posting such an announcement anymore. It indicates that all students had been registered.

In the registration step, there were no notifications from parents or students who did not agree with this policy implementation found. Most questions that arose in the communication groups were about the registration guides and the details of learning methods that would be implemented. In this case, the school management had the authority to change learning methods to become online. Students whose learning activities had stopped due to being returned home after the COVID-19 pandemic, inevitably, had to follow the policy. This finding is in line with the institutional theory which states that stronger entities can exert coercive pressure on weaker or dependent entities [22]. This is also in line with the finding which showed that the IT adoption model in the MSME sector was isomorphism, where one that influenced this behavior was the regulatory pressure [23].

Based on the observations, since online learning could be accessed through internet browsers, the devices they used for accessing it varied. Some used smartphones, while some others used laptops or desk-computers, or mixed devices. Some of them (O3 and O4) already had their own ICT devices even before the policy, but some others were lent by their parents during the online policy because they had not owned them before. Some families in Indonesia indeed provided smartphone facilities to children even from an early age, while some others did not [9], [24]-[26].

\section{Subject Matters}

The subject matters were presented by the teachers in various ways. Some teachers sent it in the form of presentation slides, some others present it in the form of reading material from textbooks, explanatory videos, and lesson points that students must find on their own via the internet.

Based on observations on the students, they seemed to be inconsistent in reading/watching/listening to the subject matter. Two observed students (O1 and O2) were usually really accessing the subject matters. However, they were also sometimes found to go directly to the assignments given without reading/watching/listening to the subject matters provided. Besides, they also sometimes only downloaded or opened subject matters, but did not read/watch/listen to them at all. When interviewed, they admitted that they did it because they targeted a higher percentage of the learning achievements which were updated and displayed in Kelase like what is shown in Figure 3. This is in line with a previous study that stated some students skipped the lesson texts or videos so that they did not get bored [7].

Besides, due to the flexible access hours, where lessons and assignments could be accessed at any time of the day ( 24 hours), both observed students became moody in opening the lessons. Sometimes they were diligent. They took the initiative independently to open the lessons their selves, to the point that they contacted their teachers to ask if the subject matters or assignments had been uploaded or not, but sometimes they were lazy and procrastinate to do it. That was why, their parents reminded them, and sometimes even force them to do it. The finding supports a previous study which stated that some of the self-regulation strategies are strong predictors of academic procrastination [27].

One of the mobile internet characteristics, which is accessible anywhere [28], seems to impact student behavior when studying online. It was found in the observation that they chose places they feel comfortable for studying. Some of them were choosing to be alone in the room, on the balcony, in the garage, or in other places. Some others chose crowded places, like the living room or television room, where other family members (relatives or parents) were also there.

BAHASA INGGRIS-VII.1-VII.2

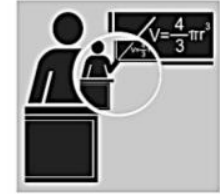

BAHASA INGGRIS-VIII.1. VII.2

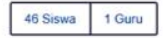

* Berand

4 Kegistan

Fig. 3 Lesson's achievement display

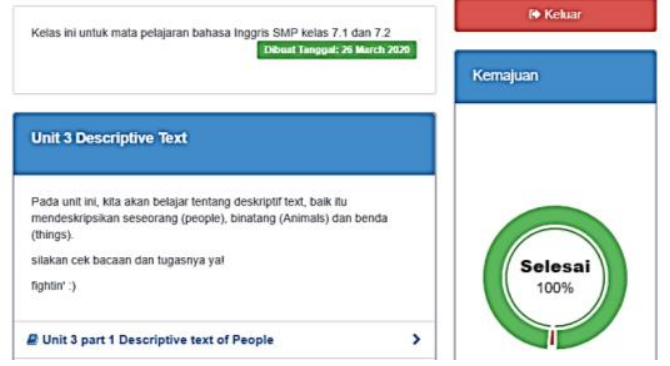


Besides, two observed students ( $\mathrm{O} 2$ and $\mathrm{O} 3$ ) had been found fell asleep while studying/doing assignments. Besides that, O1, $\mathrm{O} 2, \mathrm{O} 3$, and $\mathrm{O} 4$ got caught playing games, watching videos, and/or accessing social media, which were not related to the lessons or the achievements of the learning targets. It is in line with a previous study that found students were often tempted to access things that unrelated to their lesson when accessing the internet [8].

To use the online application, initially, the two junior students who were observed (O1 and $\mathrm{O} 2)$ were guided or assisted by their parents, but after a week of using it, they were then able to access on their own. On the other hand, three other observed students (O3, O4, and O5) who were senior students, accessed Kelase on their own, without the help of their parents. If there is something they don't understand, they asked classmates or the administrator (who was one of their teachers) who through the Telegram group. Some children indeed do not like being watched by parents. Likewise, many parents do not care much about what children access from the internet, because they think that their children understand ICT better [9], [29], [30].

\section{Assignments}

The assignments were also in a various model. Some teachers asked the students to answer questions (quiz), while some other asked the students to make summaries of the lessons, draw, or making presentation/practicum videos.

Same to the subject matters, based on observations, students were moody in My gratitude goes to the management of Yayasan Pendidikan Budi Utomo Makassar for allowing this research which is originally part of the institution's evaluation research of the implementation of online learning policies in SMP dan SMA Plus Budi utomo Makassar,doing the assignments. sometimes they were diligent, but at other times they were lazy and put off doing it. Some students $(\mathrm{O} 1, \mathrm{O} 2$, and O5) had been late submitting assignment reports. They had passed the specified deadline, so the work they did could not be uploaded anymore into Kelase. Indeed, they sometimes did not pay attention to the deadline for submission, even on the existence of the assignment. This behavior results in the nonachievement of learning targets in the Kelase update view.

After this occurred, then parents of $\mathrm{O} 1$ and $\mathrm{O} 2$ became more concerned about their children's learning achievements. After getting the Kelase accounts in the role of parents, they always checked the subjects and assignments that had been accessed and done by their children and those that had not. If there was not yet, then they would remind or sometimes force their children to read/watch/listen to subjects and do assignments. O3, O4, and O5 who are more independent had also experienced being late. After that, they relied more on their social networks to remind each other.

Until the end of the observation, about 6 weeks from the first time the learning from home policy was implemented, there were still some students who did not do the assignment within the specified time limit. This was proven by the fact that some teachers still often announced the names list of students who had and had not submitted the assignment reports. The announcement was delivered through the WhatsApp and Telegram groups.

Found in observations of the Telegram group, some students who did not do the assignment or were late to submit it complained in the group. Some revealed that too many lessons and assignments were given so that they had difficulty in allocating times, especially during the times that coincided with month Ramadhan, where they were fasting. Some claimed not to do the assignments because they did not understand and were uncomfortable with the online learning or the way of certain teachers in delivering the subject matters. Besides, some of the assignments were claimed too hard to do. Network error or signal loss also became an issue in this matter. An example of a complaint chat is shown in Figure 4. Also, $\mathrm{O} 1$ and $\mathrm{O} 2$ reported that they more likely prefer the conventional classes because assignments in there were fewer and had a longer period than the online classes.

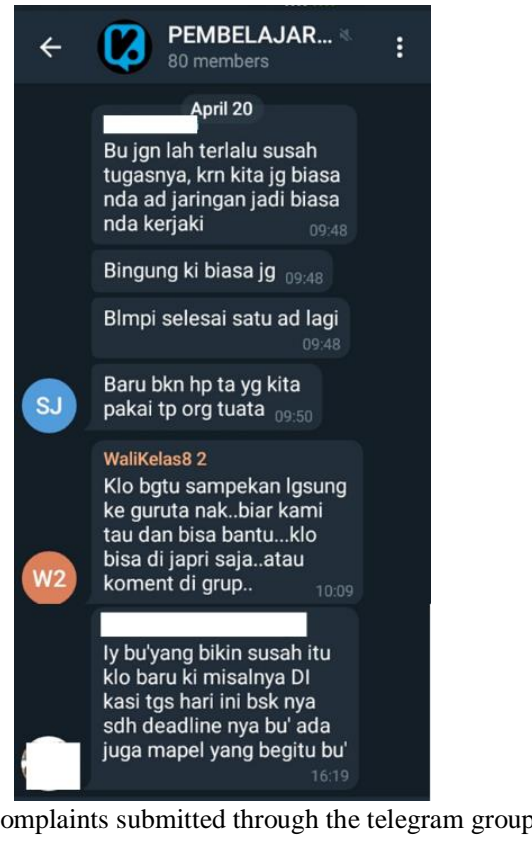

In doing the quiz task, all observed students were looking for answers from the subject matters those given by the teachers. Besides, they also discuss with classmates, or seniors through their social networks. They also sometimes use search engines, wikis, blogs, etc. to help them answer questions. They even sometimes use the internet for cheating. In the digital age, digital cheating is commonly found done by students [31]-[33].

\section{E. Communications}

The establishment of the online communication forums that involved the teachers, the students, and the parents seemed to be quite useful in this rapid change of learning methods. The group looked lively, with all-way communication from group members. The teacher used it to notify announcements to 
students, and automatically cc them to parents. Thus, the things that needed to be considered by students could be monitored and assisted by their parents. The teachers also opened opportunities for the students to consult with them about the learning, the lesson, or the assignments.

Likewise, complaints, input, and questions from students and/or parents could be accessed by all members of the group, so that they could support each other, answer, or might already be represented by group members who asked/spoke. A previous study also found the same. Students rather searched information on the internet or peers than asked their teacher [34].

Besides, it was also found that most of the group members did not use a formal language when they texted (e.g. Figure 4). They preferred to use non-standard words to do conversations. O1 reported that this way of communication was no different from conventional classroom interaction. It commonly occurred, even in other schools in Indonesia [35]-[37].

It is found that since the first step (registration) and so on of the online learning methods, some of the students preferred to ask his/her classmates for something he/she doesn't understand. It indicates the same result with studies that reported some students are reluctant/afraid/shy to ask their teacher [38]-[41]. On the contrary, some other students dared to ask the teacher or speak openly in the online chats group. This result is in line with previous studies that stated online learning increases the courage of students to ask the teacher or speak in front of the class [42]-[44]. However, online learning is not about directing students to prefer asking their social networks to their teachers [45], but it is intended to help people achieve the learning objectives [46].

\section{CONCLUSION}

With a sudden change in learning method policies, several student behaviors were discovered. School management policy that required online learning methods could not be rejected by students. Inevitably, they finally followed the policy, although some of them had difficulties when registering and/or felt more comfortable with conventional classes where assignments were fewer in number and time was less stringent.

Flexible time and place of learning results in some of them lazing around and delaying learning or doing assignments. This problem is a little solved with the support of parents who always supervise, encourage, and guide their children.

When they encountered difficulties, both in terms of application and subject matter, students tended to prefer looking for information from the internet or friends, rather than the teacher. However, some of their courage to communicate with the teacher was still there. They even dared to complain through open communication media between students, teachers, and parents about the assignments that too many, and so on. Their communication styles when online were no different from their language when in offline schools. They used non-standard language when communicating, both to the colleagues and the teachers.

\section{ACKNOWLEDGMENT}

My gratitude goes to the management of Yayasan Pendidikan Budi Utomo Makassar for allowing this research, which is originally part of the institution's evaluation research of the implementation of online learning policies in SMP dan SMA Plus Budi utomo Makassar, to be published. I am also grateful to BBPSDMP Kominfo Makassar for providing the facilities, such as laptop and free wifi network that utilized in completing this article. Last but not least, I also thank the editors and reviewers who provided input on this paper.

\section{REFERENCES}

A. Abidah, H. N. Hidaayatullaah, R. M. Simamora, D. Fehabutar, and L. Mutakinati, "The Impact of Covid-19 to Indonesian Education and Its Relation to the Philosophy of 'Merdeka Belajar," Stud. Philos. Sci. Educ., vol. 1, no. 1, pp. 38-49, 2020, [Online]. Available: https://scie-journal.com/index.php/SiPoSE/article/view/9.

R. C. Clark and R. E. Mayer, E-learning and the science of instruction: Proven guidelines for consumers and designers of multimedia learning, 4th ed. New Jersey: John Wiley \& Sons, 2016.

[3] A. Sukainah, P. P. Reski, R. Fadilah, and A. Mustarin, "Application of Technology Acceptance Model to E-learning Assessment (Kelase) in Agricultural Technology Education, UniversitasNegeri Makassar," in Journal of Physics: Conference Series, Nov. 2019, vol. 1387, p. 012115, doi: 10.1088/1742-6596/1387/1/012115.

[4] S. Hase, "Heutagogy and e-learning in the workplace: Some challenges and opportunities," Impact J. Appl. Res. Work. e-learning, vol. 1, no. 1, pp. 43-52, 2009, [Online]. Available: https://epubs.scu.edu.au/bus_pubs/72/.

[5] N. H. Waryanto and N. Insani, "Tingkat Kesiapan (Readiness) Implementasi E-Learning di Sekolah Menengah Atas Kota Yogyakarta," J. Pendidik. Mat. dan Sains, vol. 1, no. 2, pp. 117-124, 2013 , [Online]. Available: 源

N. H. Waryanto, "Evaluasi e-readiness untuk penerapan e-learning dalam proses pembelajaran sekolah menengah pertama di Kota Yogyakarta," Universitas Gajah Mada, 2010.

[7] D. Zhang, J. L. Zhao, L. Zhou, and J. F. Nunamaker, "Can e-learning replace classroom learning?," Commun. ACM, vol. 47, no. 5, pp. 7579, May 2004, doi: 10.1145/986213.986216.

[8] D. F. Dhahir, "Qur'an Memorizers and Internet: Study at Ma'had Khoir-Ul-Kayyis and Ma'had Kutubussittah Babussalam in Makassar," J. Inf. Technol. Its Util., vol. 1, no. 1, pp. 15-21, Oct. 2018, doi: 10.30818/jitu.1.1.1618.

[9] D. F. Dhahir, "Internet Parenting upon Indonesian Children," $J$. Pekommas, vol. 3, no. 2, pp. 169-178, Oct. 2018, doi: 10.30818/jpkm.2018.2030206.

[10] J. Davies and M. Graff, "Performance in e-learning: online participation and student grades," Br. J. Educ. Technol., vol. 36, no. 4, pp. 657-663, Jul. 2005, doi: 10.1111/j.1467-8535.2005.00542.x.

[11] APJII, "Laporan Survei Penetrasi \& Profil Perilaku Pengguna Inernet Indonesia," Jakarta, 2018. [Online]. Available: https://apjii.or.id/survei2018s/.

[12] A. Bencsik, T. Juhász, and G. Horváth-Csikós, "Y and Z Generations at Workplaces," J. Compet., vol. 6, no. 3, pp. 90-106, Sep. 2016, doi: 10.7441/joc.2016.03.06.

[13] T. M. Okwumabua, K. M. Walker, X. Hu, and A. Watson, "An Exploration of African American Students' Attitudes Toward Online Learning," Urban Educ., vol. 46, no. 2, pp. 241-250, Mar. 2011, doi: $10.1177 / 0042085910377516$

[14] H.-Y. Ku and L. L. Lohr, "A case study of Chinese student's attitudes toward their first online learning experience," Educ. Technol. Res. Dev., vol. 51, no. 3, pp. 95-102, Sep. 2003, doi: 10.1007/BF02504557.

[15] J. Corbin and A. Strauss, Basics of Qualitative Research: Techniques and Procedures for Developing Grounded Theory, 3rd ed. Thousand Oaks: SAGE Publications, 2008.

[16] T. M. Egan, "Grounded Theory Research and Theory Building," $A d v$. 
Dev. Hum. Resour., vol. 4, no. 3, pp. 277-295, Aug. 2002, doi: $10.1177 / 1523422302043004$

[17] M. B. Miles and A. M. Huberman, "Drawing Valid Meaning from Qualitative Data: Toward a Shared Craft," Educ. Res., vol. 13, no. 5, pp. 20-30, May 1984, doi: 10.3102/0013189X013005020.

[18] M. B. Miles, A. M. Huberman, and J. Saldaña, Qualitative Data Analysis, 3rd ed. London: SAGE Publications Ltd, 2013.

[19] K. Lazanyi, "Generation $\mathrm{Z}$ and $\mathrm{Y}$ - are they different, when it comes to trust in robots?," in 2019 IEEE 23rd International Conference on Intelligent Engineering Systems (INES), Apr. 2019, pp. 000191000194, doi: 10.1109/INES46365.2019.9109508.

[20] N. Muhadjir, Metodologi Penelitian Kualitatif. Yogyakarta: Rake Sarasin, 1996

[21] H. Hasanah, "Teknik-Teknik Observasi (Sebuah Alternatif Metode Pengumpulan Data Kualitatif Ilmu-ilmu Sosial)," At-Taqaddum, vol. 8, no. 1, pp. 21-46, Jan. 2017, doi: 10.21580/at.v8i1.1163.

[22] P. J. DiMaggio and W. W. Powell, "The Iron Cage Revisited: Institutional Isomorphism and Collective Rationality in Organizational Fields," Am. Sociol. Rev., vol. 48, no. 2, pp. 147-160, Apr. 1983, doi: 10.2307/2095101.

[23] A. Perdana, "Isomorfisma Dalam Adopsi Teknologi Informasi Pada Usaha Mikro, Kecil Dan Menengah (UMKM)," in Seminar Nasional Aplikasi Teknologi Informasi 2011 (SNATI 2011), 2011, pp. A21A28, doi: 10.2139/ssrn.1916479.

[24] N. R. Radliya, S. Apriliya, and T. R. Zakiyyah, "Pengaruh penggunaan gawai terhadap perkembangan sosial emosional anak usia dini," J. PAUD Agapedia, vol. 1, no. 1, pp. 1-12, 2017, [Online]. Available:

http://ejournal.upi.edu/index.php/agapedia/article/view/7148.

[25] Balitbang SDM Kominfo, "ICT Indicators Infographic," Jakarta, $2017 . \quad$ [Online]. Available: https://balitbangsdm.kominfo.go.id/publikasi-indikator-tik-9.htm.

[26] D. L. Fithri and D. A. Setiawan, "Analisa dan Perancangan Game Edukasi Sebagai Motivasi Belajar untuk Anak Usia Dini," Simetris J. Tek. Mesin, Elektro dan Ilmu Komput., vol. 8, no. 1, pp. 225-230, Apr. 2017, doi: 10.24176/simet.v8i1.959.

[27] H. Motie, M. Heidari, and M. A. Sadeghi, "Predicting Academic Procrastination during Self-Regulated Learning in Iranian first Grade High School Students," Procedia - Soc. Behav. Sci., vol. 69, pp. 2299-2308, Dec. 2012, doi: 10.1016/j.sbspro.2013.02.023.

[28] Seung-Que Lee, Namhun Park, Choongho Cho, Hyongwoo Lee, and Seungwan Ryu, "The wireless broadband (wibro) system for broadband wireless internet services," IEEE Commun. Mag., vol. 44, no. 7, pp. 106-112, Sep. 2006, doi: 10.1109/MCOM.2006.1668390.

[29] Y. C. Wong, "Cyber-Parenting: Internet Benefits, Risks and Parenting Issues," J. Technol. Hum. Serv., vol. 28, no. 4, pp. 252 273, Oct. 2010, doi: 10.1080/15228835.2011.562629.

[30] L. Italie, "Technology use up in kids, parents losing ground," Washington Post. 2010.

[31] G. R. Watson and J. Sottile, "Cheating in the digital age: Do students cheat more in online courses?," Online J. Distance Learn. Adm., vol. 13, no. 1, p. online, 2010, [Online]. Available: https://www.learntechlib.org/p/76542/.

[32] H. Ma, E. Y. Lu, S. Turner, and G. Wan, "An Empirical Investigation of Digital Cheating and Plagiarism among Middle School Students," Am. Second. Educ., vol. 35, no. 2, pp. 69-82, 2007, [Online]. Available: https://www.learntechlib.org/p/99902.

[33] J. M. Stogner, B. L. Miller, and C. D. Marcum, "Learning to E-Cheat: A Criminological Test of Internet Facilitated Academic Cheating," $J$. Crim. Justice Educ., vol. 24, no. 2, pp. 175-199, Jun. 2013, doi: $10.1080 / 10511253.2012 .693516$.

[34] "Predicting computer science students' online help-seeking tendencies," Knowl. Manag. E-Learning An Int. J., vol. 9, no. 1, pp. 19-32, Mar. 2017, doi: 10.34105/j.kmel.2017.09.002.

[35] S. J. Sitompul, "Interferensi Bahasa Batak Mandailing pada Penggunaan Bahasa Indonesia dalam Interaksi Kelas di Kelas VII Madrasyah Tsanawiyah Swasta," Edukasi Kult. J. Bahasa, Sastra dan Budaya, vol. 1, no. 2, pp. 99-114, 2015, [Online]. Available: https://jurnal.unimed.ac.id/2012/index.php/kultura/article/view/5184

[36] N. Hidayati, "Variasi Bahasa Pada Tuturan Guru Dan Siswa Dalam Kegiatan Komunikasi Di Lingkungan Man 3 Malang," University of
Muhammadiyah Malang, 2011.

[37] D. Giyanis, "Penggunaan Bahasa Lisan dalam Kegiatan Pembelajaran Bahasa Indonesia Siswa Kelas XI MA Al-Asy'ariyah Bandar Lampung Tahun Pelajaran 2017/2018," Universitas Negeri Lampung, 2019.

[38] E. M. Curtin, "Lessons on Effective Teaching from Middle School ESL Students," Middle Sch. J., vol. 37, no. 3, pp. 38-45, Jan. 2006, doi: 10.1080/00940771.2006.11461534.

[39] R. Pucher and M. Lehner, "Project Based Learning in Computer Science - A Review of More than 500 Projects," Procedia - Soc. Behav. Sci., vol. 29, pp. 1561-1566, 2011, doi: 10.1016/j.sbspro.2011.11.398.

[40] B. Wallace, Teaching the Very Able Child. London: David Fulton Publishers, 2012.

[41] J. T. Dillon, "A Norm against Student Questions," Clear. House A J. Educ. Strateg. Issues Ideas, vol. 55, no. 3, pp. 136-139, Nov. 1981, doi: 10.1080/00098655.1981.10113676.

[42] "Using knowledge management to improve learning experience of first-trimester students," Knowl. Manag. E-Learning An Int. J., pp. 297-315, Jun. 2015, doi: 10.34105/j.kmel.2015.07.019.

[43] I. G. P. Sudiarta and I. W. Sadra, "Pengaruh Model Blended Learning Berbantuan Video Animasi Terhadap Kemampuan Pemecahan Masalah dan Pemahaman Konsep Siswa," J. Pendidik. dan Pengajaran, vol. 49, no. 2, pp. 48-58, Dec. 2016, doi: 10.23887/jppundiksha.v49i2.9009.

[44] A. B. Rizky, "Penggunaan Media Pembelajaran Website E-Learning Berbasis Dokumen untuk Meningkatkan Hasil Belajar Siswa pada Pokok Bahasan Mengindeks Dokumen,” Econ. Educ. Anal. J., vol. 2, no. 1, pp. 100-106, 2013, [Online]. Available: http://journal.unnes.ac.id/sju/index.php/eeaj/article/view/2307. [45] W. Horton, E-learning by design, 2nd ed. San Francisco: John Wiley \& Sons, 2011.

[46] R. E. Mayer, "Elements of a Science of E-Learning," J. Educ. Comput. Res., vol. 29, no. 3, pp. 297-313, Oct. 2003, doi: 10.2190/YJLG-09F9-XKAX-753D. 